Research

\title{
Studies on the antimicrobial activity and brine shrimp toxicity of Zeyheria tuberculosa (Vell.) Bur. (Bignoniaceae) extracts and their main constituents
}

\author{
Maria Lysete A Bastos ${ }^{\dagger 1}$, Maria Raquel F Lima ${ }^{\dagger 2}$, Lucia M Conserva*2, \\ Vânia S Andrade ${ }^{\dagger 3}$, Eliana MM Rocha ${ }^{\dagger 3}$ and Rosangela PL Lemos ${ }^{\dagger 4}$
}

Address: ${ }^{1}$ Escola de Enfermagem e Farmácia, Universidade Federal de Alagoas, 57072-970, Maceió-AL, Brazil, 2Instituto de Química e Biotecnologia, Universidade Federal de Alagoas, 57072-970, Maceió-AL, Brazil, 3 Instituto de Ciências Biológicas e da Saúde, Universidade Federal de Alagoas, 57010-020, Maceió-AL, Brazil and ${ }^{4}$ Instituto do Meio Ambiente do Estado de Alagoas, 57017-320, Maceió-AL, Brazil

Email: Maria Lysete A Bastos - mlab@fapeal.br; Maria Raquel F Lima - mrfl@qui.ufal.br; Lucia M Conserva* - lmc@qui.ufal.br; Vânia S Andrade - vaniasandrade@gmail.com; Eliana MM Rocha - emmr@fapeal.br; Rosangela PL Lemos - lyralemos@uol.com.br

* Corresponding author †Equal contributors

Published: 18 May 2009

Annals of Clinical Microbiology and Antimicrobials 2009, 8:16 doi:10.1 I86/1476-07II-8-16

This article is available from: http://www.ann-clinmicrob.com/content/8/1/16

(C) 2009 Bastos et al; licensee BioMed Central Ltd.

This is an Open Access article distributed under the terms of the Creative Commons Attribution License (http://creativecommons.org/licenses/by/2.0), which permits unrestricted use, distribution, and reproduction in any medium, provided the original work is properly cited.
Received: 18 March 2009

Accepted: 18 May 2009

\begin{abstract}
Background: Due to the indiscriminate use of antimicrobial drugs, the emergence of human pathogenic microorganisms resistant to major classes of antibiotics has been increased and has caused many clinical problems in the treatment of infectious diseases. Thus, the aim of this study was to evaluate for the first time the in vitro antimicrobial activity and brine shrimp lethality of extracts and isolated compounds from Zeyheria tuberculosa (Vell.) Bur., a species used in Brazilian folk medicine for treatment of cancer and skin diseases.

Methods: Using the disc diffusion method, bioautography assay and brine shrimp toxicity test (Artemia salina Leach), we studied the antimicrobial activity and lethality of extracts and isolated compounds against three microorganisms strains, including Gram-positive (Staphylococcus aureus) and Gram-negative (Pseudomonas aeruginosa) bacteria and yeasts (Candida albicans).

Results: In this study, the extracts inhibited S. aureus $(8.0 \pm 0.0$ to $14.0 \pm 0.0 \mathrm{~mm})$ and C. albicans $(15.3 \pm 0.68$ to $25.6 \pm 0.4 \mathrm{~mm}$ ) growth. In the brine shrimp test, only two of them showed toxic effects $\left(\mathrm{LC}_{50} 29.55\right.$ to 398.05 $\mu \mathrm{g} / \mathrm{mL})$ and some extracts were non-toxic or showed weak lethality $\left(\mathrm{LC}_{50} 705.02\right.$ to $\left.>1000 \mu \mathrm{g} / \mathrm{mL}\right)$. From these extracts, four flavones [5,6,7,8-tetramethoxyflavone (I), 5,6,7-trimethoxyflavone (2), 4'-hydroxy-5,6,7,8tetramethoxyflavone (3), and 4'-hydroxy-5,6,7-trimethoxyflavone (4)] were isolated through bioassay-guided fractionation and identified based on the ID and 2D NMR spectral data. By bioautography assays, compounds I [S. aureus $(16.0 \pm 0.0 \mathrm{~mm})$ and C. albicans $(20.0 \pm 0.0 \mathrm{~mm})$ ] and 3 [S. aureus $(10.3 \pm 0.6 \mathrm{~mm})$ and C. albicans $(19.7$ $\pm 0.6 \mathrm{~mm})]$ inhibited both microorganisms while 2 inhibited only S. aureus ( $11.7 \pm 0.6 \mathrm{~mm})$. Compound 4 did not restrain the growth of any tested microorganism.

Conclusion: Our results showed that extracts and isolated flavones from $Z$. tuberculosa may be particularly useful against two pathogenic microorganisms, S. aureus and $C$. albicans. These results may justify the popular use this species since some fractions tested had antimicrobial activity and others showed significant toxic effects on brine shrimps. However, in order to evaluate possible clinical application in therapy of infectious diseases, further studies about the safety and toxicity of isolated compounds are needed.
\end{abstract}




\section{Background}

The research into biologically active compounds from natural sources has always been of great interest for scientists looking for new sources of useful drugs against infectious diseases [1]. It is known that the antibiotics commonly used are sometimes associated with adverse effects on the host [2-4]. In recent years, resistance to these drugs by pathogenic bacteria microorganisms has increased and this had caused serious clinical problems in the treatment of infectious diseases [5,6].

The effects of antibiotic resistance have been reflected in the agriculture, food, medical, and pharmaceutical industries. Though pharmacological industries have produced a number of new antibiotics, in the last three decades, yet resistance to these drugs by microorganisms has developed. According to the WHO, medicinal plants would be the best source for obtaining a variety of drugs and a possible way to treat diseases caused by multidrug resistant bacteria [7]. Thus, the in vitro antimicrobial activity could provide the needed preliminary observations necessary to select medicinal plants with potentially useful properties for to develop novel antibiotic prototypes [8].

In Brazil, the most common genera of the family Bignoniaceae are Zeyheria and Tabebuia. They are of economic importance because of its use in the civil construction, furniture manufacturing, paper production, and in urban architecture as ornamental trees [9]. The genus Zeyheria comprises about 120 genera and 800 species characterized to be arborous plants which are spread in the tropical regions throughout the world [10]. In Brazil, it comprises only two native species $(Z$. digitalis Hoehne \& Kuhlm. and $Z$. tuberculosa). From the trunk wood and twigs of $Z$. tuberculosa four naphthoquinones (lapachol, $\alpha$-dehydrolapachone, $\alpha$-lapachone, and 4-hydroxy- $\alpha$-lapachone), two terpenoids ( $\beta$-amyrin and $\beta$-sitosterol) and a lignan (zeyherol) have been isolated $[11,12]$ while from leaves only two flavones (5,6,7-trimethoxyflavone and 5,6,7,8tetramethoxyflavone) [13].

The aim of this investigation was to evaluate for the first time the in vitro antimicrobial activity and brine shrimp lethality of extracts and isolated compounds from Z $Z$. tuberculosa, popularly known as "ipê-preto", against three strains of microorganisms (S. aureus, $P$. aeruginosa and $C$. albicans). This plant was selected because in Brazil it has been used for treatment of cancer and skin diseases [11] and there is no antimicrobial study on this species.

\section{Methods}

General experimental procedures

Hexane, chloroform $\left(\mathrm{CHCl}_{3}\right)$, ethyl acetate (EtOAc), methanol $(\mathrm{MeOH})$, and dimethylsulfoxide (DMSO) analytical grade were purchased from Quimex (F. Maia Indús- tria e Comércio Ltda, Brazil) or Vetec (Vetec Química Fina Ltda, Rio de Janeiro, Brazil) while Saboraud dextrose agar (SDA), Brain Infusion Heart (BIH) and Mueller Hinton agar (MHA) were purchased from Acumedia Manufacturers Inc. (MI, USA). Staphylococcus aureus (ATCC 25923), Pseudomonas aeruginosa (ATCC 27853) and Candida albicans (ATCC 10231) strains were obtained from the American Type Culture Collection (ATCC, Manassas, VA, USA). Sterile discs of vancomycin, ciprofloxacin and miconazole, gentamicin and 2,3,5-triphenyltetrazolium chloride (TTC) were purchased from Sigma Co (St Louis, MO, USA). Brine shrimp (Artemia salina Leach) eggs were bought from Sea Word Comercial Ltda (Maceió, AL, Brazil). Seawater was collected from the Atlantic Ocean, along the North Coast, Alagoas State, Brazil. 1D and 2D NMR spectra were recorded on a Bruker Avance 400 spectrometer $\left({ }^{1} \mathrm{H}: 400 \mathrm{MHz}\right.$ and $\left.{ }^{13} \mathrm{C}: 100 \mathrm{MHz}\right)$. Column chromatography (CC) were performed on silica gel 60 (70-230 and 230-400 mesh, Merck, Darmstadt, Germany) and Sephadex LH-20 (Pharmacia). Silica gel 60 $\mathrm{F}_{254}$ (Merck, Darmstadt, Germany) coated aluminum plates were used for thin-layer chromatography (TLC) and in the bioautography assays.

\section{Plant material}

Stems of $Z$. tuberculosa were collected in June 2005, at the farm Camarão, municipality of Boca da Mata, Alagoas State, Brazil, and identified by Rosangela P. L. Lemos of the Instituto do Meio Ambiente do Estado de Alagoas, where a voucher specimen was deposited (MAC-23816).

\section{Preparation of the extracts and isolation of the constituents}

The air-dried and powdered stems $(900 \mathrm{~g})$ were extracted at room temperature with ethanol (EtOH) $90 \%$. The solution was filtered using Whatman $\mathrm{N}^{\circ} 1$ filter paper under suction and concentrated to dryness at $50^{\circ} \mathrm{C}$ under reduced pressure. The obtained EtOH extract $(7.72 \mathrm{~g})$ was partitioned between hexane, chloroform $\left(\mathrm{CHCl}_{3}\right)$ and hydro-alcoholic $\left(\mathrm{MeOH}-\mathrm{H}_{2} \mathrm{O}, 7: 3\right)$ solution. After that, the methanol $(\mathrm{MeOH})$ was removed under vacuum and the aqueous portion was further extracted with ethyl acetate (EtOAc). Hexane extract $(2.9 \mathrm{~g})$ was separated into neutral $(1.4 \mathrm{~g})$ and acid (1.5 g) constituents with $\mathrm{NaOH}$ $2 \%$. All extracts from these procedures $[\mathrm{EtOH}$, hexane acid $(1.4 \mathrm{~g})$, hexane neutral $(1.42 \mathrm{~g}), \mathrm{CHCl}_{3}(2.6 \mathrm{~g})$, EtOAc (0.6 $\mathrm{g})$, and $\left.\mathrm{MeOH} \mathrm{H}_{2} \mathrm{O}(1.5 \mathrm{~g})\right]$ were evaluated as antimicrobial by disc diffusion method and for lethality to brine shrimp larvae (Artemia salina Leach).

The chloroform extract $(2.6 \mathrm{~g})$, the most promising in the antimicrobial assays $[12.3 \pm 0.71 \mathrm{~mm}$ (S. aureus) and 18.3 $\pm 0.4 \mathrm{~mm}$ (C. albicans)], was further fractionated on silica gel column (70-230 mesh) with hexane- $\mathrm{CHCl}_{3} 1: 1(1.2 \mathrm{~g})$, $\mathrm{CHCl}_{3}(0.44 \mathrm{~g}), \mathrm{CHCl}_{3}-\mathrm{MeOH}$ 1:1 (1.65 g), and $\mathrm{MeOH}$ 
(0.02 g). These fractions were also evaluated and $\mathrm{CHCl}_{3}$ fraction $(0.44 \mathrm{~g})$, the most active as antimicrobial (14.0 \pm 0.0 and $25.6 \pm 0.4 \mathrm{~mm}$ for $S$. aureus and C. albicans, respectively), was fractioned on a silica gel column (70-230 mesh) using hexane containing increasing amounts of EtOAc. Two remaining sub-fractions [53-60 (0.05 g) and 71-74 (0.04 g)] after gel permeation (Sephadex LH-20 with $\mathrm{MeOH})$ and successive recrystallizations from $\mathrm{MeOH}$ afforded 1 (25 mg) and 2 (20 mg), respectively. The $\mathrm{CHCl}_{3}$ $\mathrm{MeOH} \mathrm{1:1} \mathrm{fraction} \mathrm{(1.65} \mathrm{g),} \mathrm{active} \mathrm{as} \mathrm{antimicrobial} \mathrm{(8.0 \pm}$ 0.0 and $15.3 \pm 0.68 \mathrm{~mm}$ for $S$. aureus and C. albicans, respectively), after successive chromatographic fractionations [silica gel (230-400 mesh, $\mathrm{CHCl}_{3}$ containing increasing amounts of $\mathrm{MeOH}$ ) and Sephadex LH-20 (MeOH)] afforded 3 (5 mg) and 4 (7 mg). These compounds were further evaluated using bioautography assay.

\section{Antimicrobial assays}

In this study, strains of $S$. aureus (ATCC 25923), P. aeruginosa (ATCC 27853) and C. albicans (ATCC 10231) were used to investigate the antimicrobial potential of the extracts and isolated constituents by disc diffusion method [14]. Stock solutions of the samples [crude extract (50 mg/ $\mathrm{mL})$ and fractions $(25 \mathrm{mg} / \mathrm{mL})]$ were prepared in chloroform or methanol (HPLC degree, Merck). Further, these solutions were then diluted to give final concentrations ranging from 6.25 to $1000 \mu \mathrm{g} /$ disc and kept at $4{ }^{\circ} \mathrm{C}$ prior to use. Sterile discs ( $6 \mathrm{~mm}$ diameter) of vancomycin $(30 \mu \mathrm{g})$, ciprofloxacin $(5 \mu \mathrm{g})$, and miconazole $(50 \mu \mathrm{g})$ were used as positive controls. In order to avoid any effect of the solvent, methanol and chloroform were used as negative controls. The microorganism cultures were grown in Brain Infusion Heart (BIH) liquid medium at $35^{\circ} \mathrm{C}$ (for bacteria) and $28^{\circ} \mathrm{C}$ (for yeast), and the microorganisms were kept under refrigeration $\left(4^{\circ} \mathrm{C}\right)$ until use. After $24 \mathrm{~h}$ (for bacteria) and $48 \mathrm{~h}$ (for yeast) of growth, each microorganism, at a concentration of $1.5 \times 10^{6}$ cells/mL (adjusted to the $0.5 \mathrm{McFar}-$ land turbidity standards) $[15,16]$, was inoculated on the surface of Mueller Hinton agar (for bacteria) and Saboraud dextrose agar (for yeast) plates. Sterile filter paper discs (6 $\mathrm{mm}$ in diameter) saturated either with extract or fractions were impregnated, in triplicate, with $20 \mu \mathrm{L}$ of the stock solutions (1000 and $500 \mu \mathrm{g} /$ disc for extract and fractions, respectively) on surface of each inoculated plate. After holding the plates at room temperature for $1 \mathrm{~h}$ to allow diffusion of test samples into the agar, they were incubated [17]. After that, the results were recorded by measuring the zones of growth inhibition around the discs, and presented as the arithmetic average (mean value \pm standard deviation). Overall, cultured microorganisms with halos equal to or greater than $7 \mathrm{~mm}$ were considered susceptible to samples tested. The data were analyzed using the statistical method of PROBIT analysis with the aid of the SPSS 11.5 computation package (SPSS Inc., Chicago, Illinois, USA).

\section{Bioautography assay}

Isolated compounds (1-4) were evaluated by bioautography technique [18]. An aliquot each sample dissolved in chloroform or methanol or mixture of both [bacteria $(10 \mu \mathrm{g})$ and yeast $(50 \mu \mathrm{g})]$ was applied over a chromatosheet of silica gel $60 \mathrm{~F}_{254}$ followed by elution with a system of hexane-EtOAc (7:3) and air-drying. Further, a layer of Mueller Hinton agar medium (for bacteria) or Saboraud dextrose agar (for yeast) containing $1.5 \times 10^{6}$ cells/mL of each microorganism suspension separately was inoculated and sprayed with fresh culture over a developed TLC plate and incubated for $24 \mathrm{~h}$ at $35^{\circ} \mathrm{C}$ (for bacteria) and $48 \mathrm{~h}$ at $28^{\circ} \mathrm{C}$ (for yeast). Each treatment was replicated three-times and gentamicin $(10 \mu \mathrm{g})$, miconazole $(50 \mu \mathrm{g})$, solvents and samples-free solutions were used as drugs controls and blank. The inhibition of growth by the compounds on the plates was visualized as white spots against the deep red background after spraying the plates with 2,3,5-triphenyltetrazolium chloride aqueous solution $(2.0 \mathrm{mg} / \mathrm{mL})$. The results were recorded by measuring the zones of growth inhibition around the spots and presented as the arithmetic average (mean value \pm standard deviation).

\section{Brine shrimp toxicity assay}

The most promising as antimicrobial fractions (hexane acid, hexane- $\mathrm{CHCl}_{3} 1: 1, \mathrm{CHCl}_{3}$, and $\mathrm{CHCl}_{3}-\mathrm{MeOH}$ 1:1) were evaluated for lethality to brine shrimp larvae (A. salina Leach) according to the procedures described by Meyer et al. [19] and Solis et al. [20]. Brine shrimp eggs were hatched for $48 \mathrm{~h}$ in a conical flask containing 300 $\mathrm{mL}$ of seawater. The flasks were well aerated with the aid of an air pump and kept in a water bath at $29-30^{\circ} \mathrm{C}$. A bright light source was left on and the nauplii hatched within $48 \mathrm{~h}$. The fractions were dissolved in $1 \%$ aqueous DMSO to obtain a concentration of $1 \mathrm{mg} / \mathrm{mL}$. These were serially diluted three-times and different concentrations were obtained ( 1000 to $12.5 \mu \mathrm{g} / \mathrm{mL}$ ). An aliquot of each concentration ( $1 \mathrm{~mL}$ ) was transferred, in triplicate, into clean sterile universal vials with pipette, and aerated seawater $(9 \mathrm{~mL})$ was added. Ten shrimp nauplii were transferred to each vial (30 shrimps per concentration). Thymol 1\% aqueous solution [21] and 1\% DMSO in seawater were used as positive and negative controls, respectively. After 24 h the numbers of survivors were counted and percentage of death calculated. The concentration that killed $50 \%$ of the nauplii ( $\mathrm{LC}_{50}$ in $\mu \mathrm{g} / \mathrm{mL}$ and Confidence Intervals 95\%) was determined using the statistical method of PROBIT analysis with the aid of the SPSS 11.5 computation package (SPSS Inc., Chicago, IL, USA) [22]. Criterion of toxicity for fractions was established according to Déciga-campos et al. [23]: LC $_{50}$ values > $1000 \mu \mathrm{g} / \mathrm{mL}$ (non-toxic), $\geq 500 \leq 1000 \mu \mathrm{g} / \mathrm{mL}$ (weak toxicity) and $<500 \mu \mathrm{g} / \mathrm{mL}$ (toxic). 


\section{Results \\ Antimicrobial activity}

In this study, no negative controls exhibited antimicrobial activity and compared with positive controls [vancomycin $(15.0 \pm 0.51 \mathrm{~mm})$ and miconazole $(26.0 \pm 0.68 \mathrm{~mm})]$, the extracts had significant inhibition against $S$. aureus and $C$. albicans. In general, medium inhibition zones ranged from $9.0 \pm 0.0$ to $13.7 \pm 0.71 \mathrm{~mm}$ and $10.7 \pm 0.0$ to 25.6 $\pm 0.4 \mathrm{~mm}$ for $S$. aureus and C. albicans, respectively. Among extracts tested, three of the fractions from chromatographic fractionation effectively inhibited the growth of both microorganisms [hexane- $\mathrm{CHCl}_{3}$ 1:1 (S. aureus: 13.7 $\pm 0.71 \mathrm{~mm}$; C. albicans: $21.0 \pm 0.7 \mathrm{~mm}), \mathrm{CHCl}_{3}(S$. aureus: $14.0 \pm 0.0 \mathrm{~mm}$; C. albicans: $25.6 \pm 0.4 \mathrm{~mm})$, and $\mathrm{CHCl}_{3}-$ MeOH 1:1 (S. aureus: $8.0 \pm 0.0 \mathrm{~mm}$; C. albicans: $15.3 \pm 0.7$ $\mathrm{mm})]$ while hexane extract $(19.0 \pm 0.0 \mathrm{~mm})$ and one of its fractions [hexane acid $(17.3 \pm 0.0 \mathrm{~mm})$ ] inhibited only $C$. albicans. On the other hand, ethyl acetate and hydro-alcoholic extracts not inhibited the growth of any tested microorganisms. No extract tested inhibited $P$. eruginosa growth.

\section{Brine shrimp lethality}

In the brine shrimp test, among extracts evaluated, two of the fractions $\left[\mathrm{CHCl}_{3}-\mathrm{MeOH} 1: 1(\mathrm{LC} 50>1000 \mu \mathrm{g} / \mathrm{mL})\right.$ and $\mathrm{CHCl}_{3}\left(\mathrm{LC}_{50} 705.02 \mu \mathrm{g} / \mathrm{mL} ; \mathrm{CI}_{95} 422.16-868.03 \mu \mathrm{g} /\right.$ $\mathrm{mL})]$ were nontoxic or exhibited weak toxicity. On the other hand, hexane acid ( $\mathrm{LC}_{50} 29.55 \mu \mathrm{g} / \mathrm{mL}$; $\mathrm{CI}_{95} 24.67-$ $34.99 \mu \mathrm{g} / \mathrm{mL})$ and hexane- $\mathrm{CHCl}_{3} 1: 1\left(\mathrm{LC}_{50} 398.05 \mu \mathrm{g} / \mathrm{mL}\right.$; $\mathrm{CI}_{95} 299.14-560.08 \mu \mathrm{g} / \mathrm{mL}$ ) fractions showed significant toxic effects. In this assay, the positive control [thymol (1\%)] showed significant toxicity $\left(\mathrm{LC}_{50} 2.9 \mu \mathrm{g} / \mathrm{mL}_{;} \mathrm{CI}_{95}\right.$ $2.3-3.3 \mu \mathrm{g} / \mathrm{mL})$.

\section{Phytochemical investigation}

From two fractions of promising $\left[\mathrm{CHCl}_{3}\right.$ (S. aureus: $14.0 \pm$ $0.0 \mathrm{~mm}$ and C. albicans: $25.6 \pm 0.4 \mathrm{~mm}$ ) and $\mathrm{CHCl}_{3-}$ MeOH 1:1 (S. aureus: $8.0 \pm 0.0 \mathrm{~mm}$ and C. albicans: 15.3 $\pm 0.68 \mathrm{~mm})]$, compounds $1-4$ were isolated by monitored chromatographic fractionation. Based on the $1 \mathrm{D}$ and $2 \mathrm{D}$ NMR spectral data $\left({ }^{1} \mathrm{H},{ }^{13} \mathrm{C}, \mathrm{DEPT}, \mathrm{HMQC}\right.$ and HMBC) as well as comparison with described values, they were identified as 5,6,7,8-tetramethoxyflavone (1) [13,24], 5,6,7-trimethoxyflavone (2) [13,25], 4'-hydroxy5,6,7,8-tetramethoxyflavone (3) [26,27], and 4'-hydroxy5,6,7-trimethoxyflavone (4) [28] (Figure 1). Among them, compounds 3 and 4 are being described for the first time in the genus Zeyheria. When compared to positive controls [gentamicin $(15.0 \pm 0.25 \mathrm{~mm})$ and miconazole $(26.0 \pm 0.0 \mathrm{~mm})]$, compounds 1 and 3 inhibited both $S$. aureus $(1: 16.0 \pm 0.0 \mathrm{~mm} ; 3: 10.3 \pm 0.6 \mathrm{~mm})$ as $C$. albicans $(1: 20.0 \pm 0.0 \mathrm{~mm} ; 3: 19.7 \pm 0.6 \mathrm{~mm})$ while 2 inhibited only $S$. aureus $(11.7 \pm 0.6 \mathrm{~mm})$ and $4 \mathrm{did}$ not restrain the growth of any tested microorganism.

\section{Discussion}

Plants are known to produce some chemical constituents, which are naturally toxic to bacteria and fungi [29]. Traditionally they are used to treat systemic bacterial and yeast infections, as well applied directly on the skin or nails in a plaster form to treat local infections [30]. Despite the significant progress made in molecular biology and synthetic chemistry that can lead to the development of new drugs, plants have been a potential source of bioactive compounds. In this study, extracts from stems of $Z$. tuberculosa showed to be effective against $S$. aureus and C. albicans, pathogenic microorganisms known to constitute a significant cause of nosocomial infection and morbidity mainly among immune compromised and severely ill patients [31,32].

Although there are some reports showing that polar extracts inhibited the growth of both Grampositive and Gram-negative bacteria [33,34], in the present study, crude ethanol extract $[S$. aureus $(9.0 \pm 0.16 \mathrm{~mm})$ and $C$. albicans $(17.3 \pm 0.4 \mathrm{~mm})]$ inhibited only the growth of $S$. aureus (Gram-positive) and C. albicans (yeast). This extract was partitioned and only two of remaining extracts (hexane and chloroform) showed significant against $S$. aureus and/or C. albicans, and no activity was observed for the most polar extracts (ethyl acetate and hydroalcoholic).

Several studies have shown that brine shrimp assay has been an excellent method for preliminary investigations of toxicity, to screen medicinal plants popularly used for several purposes and for monitoring the isolation a great variety of biologically active compounds [35]. The technique is easily mastered, costs little, and utilizes small amount of test material. Since its introduction [19], this in vivo test has been successively employed for bioassayguide fractionation of active cytotoxic and antitumor agents [36]. Furthermore, a positive correlation between the lethality to brine shrimp and the corresponding oral lethal dose in mice of medicinal plants has been demonstrated by Parra et al. [37]. The results obtained in this study may be support the popular use of $Z$. tuberculosa in Brazil for the treatment of cancer since some fractions showed significant toxic effects on brine shrimps.

From the chloroform and $\mathrm{CHCl}_{3}-\mathrm{MeOH}$ 1:1 fractions, four flavones (1-4) were isolated and also evaluated through bioautography assay against the same microorganisms previously mentioned. Our results showed that the response in terms of susceptibility the response to the microorganism tested varied among them. Compounds 1 and 3, which have four methoxyl groups in the ring A, were actives for $S$. aureus and $C$. albicans while compound 2 (5,6,7-trimethoxyflavone), which lacks a methoxyl group at C-8 of this ring, was active only for C. albicans. 
<smiles>[R]c1ccc(-c2cc(=O)c3c(OC)c(OC)c(OC)c([R])c3o2)cc1</smiles>

$$
\begin{aligned}
& \text { 5,6,7,8-Tetramethoxyflavone (1): } \mathrm{R}=\mathrm{OMe}, \mathrm{R}_{1}=\mathrm{H} \\
& \text { 5,6,7-Trimethoxyflavone (2): } \mathrm{R}=\mathrm{R}_{1}=\mathrm{H} \\
& \text { 4'-Hydroxy-5,6,7,8-tetramethoxyflavone (3): } \mathrm{R}=\mathrm{OMe}, \mathrm{R}_{1}=\mathrm{OH} \\
& \text { 4'-Hydroxy-5,6,7-trimethoxyflavone (4): } \mathrm{R}=\mathrm{H}, \mathrm{R}_{1}=\mathrm{OH}
\end{aligned}
$$

Figure I

\section{Chemical structures of isolated compounds.}

On the other hand, compound 4 (4'-hydroxy-5,6,7-trimethoxyflavone), which lacks a methoxyl group at C-8 and has a hydroxyl group at C-4', in comparison with the similar compound 3, did not affect the growth of the tested microorganisms. These results suggested that the presence of methoxyl group at C-8 can be responsible for the antibacterial activity and that minor structural differences among these flavones influence their antimicrobial activity, bringing new perspectives to studies on the structure-activity relationship of this type of metabolites.

\section{Conclusion}

In Brazil, the species $Z$. tuberculos $a$ has been used in traditional medicine for treatment of cancer and skin diseases. Then, the results obtained in this study may justify the popular use this species since some fractions tested had antimicrobial activity and others showed significant toxic effects on brine shrimps. In addition, our results demonstrated that flavones isolated from this species present in vitro antimicrobial activity. However, in order to evaluate possible clinical application in therapy of infectious diseases, further studies about the safety and toxicity of the isolated compounds are needed.

\section{Competing interests}

The authors declare that they have no competing interests.

\section{Authors' contributions}

MLAB was involved in experimental work, designing the study, data acquisition and analysis, literature search, and revising the manuscript. MRFL provided assistance in brine shrimp lethality assay. LMC was responsible for study concept, designing and coordinating the research and writing the manuscript. VSA and EMMR were involved in experimental work, designing the study, data interpretation, and supervised the work. RPLL collected and identified plant material.

All authors read and approved the final manuscript.

\section{Acknowledgements}

This study was supported by grants from the Conselho Nacional de Desenvolvimento Científico e Tecnológico $(\mathrm{CNPq})$, Fundação de Amparo à Pesquisa do Estado de Alagoas (FAPEAL), Ministério da Ciência e Tecnologia-Instituto do Milênio do Semi-Árido (MCTIMSEAR), and Banco do Nordeste-Rede Nordestina de Biotecnologia (BNB-RENORBIO).

\section{References}

I. Cohen ML: Epidemiology of drug resistance: implications for a post antimicrobial era. Science 1992, 257: 1050-1055.

2. Prasad R, Kapoor K: Multidrug resistance in yeast Candida. Int Rev Cytol 2005, 242:2I 5-248.

3. Schinor EC, Salvador MJ, Ito IY, Dias DA: Evaluation of the antimicrobial activity of crude extracts and isolated constituents from Chresta scapigera. Braz J Microbiol 2007, 38: 145 - 149.

4. De Lencastre H, Oliveira D, Tomasz A: Antibiotic resistant Staphylococcus aureus: a paradigm of adaptive power. Curr Opin Microbiol 2007, 10:428-435.

5. Mishra NN, Prasad T, Sharma N, Paysi A, Prasad R, Gupta DK, Singh $R:$ Pathogenicity and drug resistance in Candida albicans and other yeast species. A review. Acta Microbiol Immunol Hung 2007, 54:20I-235.

6. Torres JA, Villegas MV, Quinn JP: Current concepts in antibioticresistant Gramnegative bacteria. Expert Rev Anti Infect Ther 2007, 5:833-843.

7. Bhattacharjee I, Chatterjee SK, Chatterjee S, Chandra G: Antibacterial potentiality of Argemone mexicana solvent extracts against some pathogenic bacteria. Mem Inst Oswaldo Cruz 2006, 101:645-648.

8. Koduru S, Grierson DS, Afolayan AJ: Antimicrobial activity of Solanum aculeastrum. Pharm Biol 2006, 44(4):283-286.

9. Lorenzi H: Árvores brasileiras: manual de identificação e cultivo de plantas arbóreas nativas do Brasil. São Paulo: Ed. PlantarumNova Odessa; 1998. 
10. Joly $\mathrm{AB}$ : Botânica: Introducão à taxonomia vegetal. São Paulo: Companhia Editora Nacional; 1998.

II. Weinberg MLD, Gottlieb OR, De Oliveira GG: The chemistry of Brazilian Bignoniaceae. Part 2. Naphthoquinones from Zeyhera tuberculosa. Phytochemistry 1976, 15:570.

12. Gupta RB, Khanna RN: An unambiguous synthesis of 4-hydroxyalpha -lapachone and its beta isomer. Indian J Chem 1978, I6B():35.

13. Kutney JP, Hanssen HW: 5,6,7-Trimethoxyflavone and 5,6,7,8tetramethoxyflavone from Zeyhera tuberculosa. Phytochemistry 1971, 10:3298-3302.

14. Bauer AW, Kirby E, Sherris EM, Turk M: Antibiotic by standardized single disk method. Am J Clin Pathol 1966, 45:493-496.

15. National Committee for Clinical Laboratory Standards: Methods for dilution antimicrobial susceptibility tests for bacteria that grow aerobically: approved standard - 8th ed., NCCLS document M7-A6 and MIC testing supplemental tables MI00SI3 - 6th ed. NCCLS, Wayne, Pennsylvania, USA; 2003.

16. National Committee for Clinical Laboratory Standards: National Committee for clinical laboratory standards for antimicrobial disk susceptibility tests: approved standards. 6th edition. NCCLS, Wayne, Pennsylvania, USA; 2005.

17. Chandrasekaran M, Venkatesalu V: Antibacterial and antiyeast activity of Syzygium jabolanum seeds. J Ethnopharmacol 2004, 9I:105-108.

18. Silva MTG, Simas SM, Batista TGFM, Cardarelli P, Tomassini TCB: Studies on antimicrobial activity, in vitro, of Physalis angulata L. (Solanaceae) fraction and physalin B bringing out the importance of assay determination. Mem Inst Oswaldo Cruz 2005, 100:779-782.

19. Meyer N, Ferrigni NR, Putnam JE: Brine shrimp: a convenient general bioassay for active plant constituents. Planta Med 1982, 45:31-32.

20. Solis PN, Wright CW, Anderson MM, Gupta MP, Phillipson D: A microwell cytotoxicity using Artemia salina (Brine shrimp). Planta Med 1992, 59:250-252.

21. Ellis MD, Baxendale FP: Toxicity of seven monoterpenoids to tracheal mites (Acari : Tarsonemidae) and their honey bee (Hymenoptera : Apidae) hosts when applied as fumigants. J Econ Entomol 1997, 90:1087-1091.

22. Finney DJ: Probit Analises. Cambridge: Cambridge University Press; I971.

23. Déciga-Campos M, Rivero-Cruz I, Arriaga-Alba M, Castañeda-Corral G, Angeles-López GE, Navarrete A, Mata R: Acute toxicity and mutagenic activity of Mexican plants used in traditional medicine. J Ethnopharmacol 2007, I 1 0:334-342.

24. Bohlmann F, Zdero C, Ziesche J: Neue flavone und phloroglucinderivate aus helichrysum herbaceum und helichrysum chrysargyrum. Phytochemistry 1978, 18:1375-1378.

25. Tomás-Barberán FA, Msonthi JD, Hostettmann K: Antiyeast epicuticular methylated flavonoids from Helichrysum nitens. Phytochemistry 1988, 27:753-755.

26. Agrawal PK, Thakur RS, Bansal MC: Flavonoids. In Studies in Organic Chemistry: Carbon-I 3 NMR of flavonoids Edited by: Agrawal PK. New York: Elsevier; 1989.

27. Buisson D, Quintin J, Lewin G: Biotransformation of polymethoxylated flavonoids: access to their 4'-O-demethylated metabolites. J Nat Prod 2007, 70:1035-1038.

28. Yen $\mathrm{M}-\mathrm{H}, \mathrm{Wu}$ ESC: Chromones and chromone derivates and uses thereof. Patent-WO/2004/037/93, PCT/US2003/033578, USA 2004.

29. Basile A, Giordano S, López-Sáez JA, Cobianchi RC: Antibacterial activity of pure flavonoids isolated from mosses. Phytochemistry 1999, 52: |479-| 482.

30. Yang X, Summerhurst DK, Koval SF, Ficker C, Smith MI, Bernards MA: Isolation of an antimicrobial compound from Impatiens balsamina $\mathrm{L}$. using bioassay-guided fractionation. Phytother Res 200I, I5:676-680.

31. Abi-Said D, Anaissie E, Uzun O, Raad I, Pinzcowski H, Vartivarian S: The epidemiology of hematogenous candidiasis caused by different Candida species. Clin Infect Dis 1997, 24: I I22-I I 28.

32. Lowy FD: Staphylococcus aureus infections. New EnglJ Med I998, 339:520-532.

33. Masika PJ, Afolayan AJ: Antimicrobial activity of some plants used for the treatment of livestock diseases in Eastern Cape, South Afr. J Ethnopharmacol 2002, 83: 129-134.
34. Karaman I, Sahin F, Güllüce M, Ögütçü H, Sngül M, Adigüzel A: Antimicrobial activity of aqueous and methanol extracts of Juniperus oxycedrus L. J Ethnopharmacol 2003, 85:23I-235.

35. Quignard EL, Pohlit AM, Nunomura SM, Pinto AC, Santos EV, Morais SK, Alecrim AM, Pedroso AC, Cyrino BR, Melo CS, Finney EK, Gomes EO, Souza KS, Oliveira LC, Don LC, Silva LF, Queiroz MM, Henrique MC, Santos M, Pinto PS, Silva SG: Screening of plants found in Amazonas state for lethality towards brine shrimp. Acta Amazon 2003, 33:93-104.

36. Pisutthanan S, Plianbangchang P, Pisutthanan N, Ruanruay S, Muanrit $O$ : Brine shrimp lethality activity of Thai medicinal plants in the family Meliaceae. Naresuan Univ J 2004, I 2:13-18.

37. Parra AL, Yhebra RS, Sardinas IG, Buela LI: Comparative study of the assay of Artemia salina $\mathrm{L}$. and the estimate of the medium lethal dose $\left(\mathrm{LD}_{50}\right.$ value) in mice, to determine oral acute toxicity of plant extracts. Phytomedicine 200I, 8:395-400.
Publish with BioMed Central and every scientist can read your work free of charge

"BioMed Central will be the most significant development for disseminating the results of biomedical research in our lifetime. "

Sir Paul Nurse, Cancer Research UK

Your research papers will be:

- available free of charge to the entire biomedical community

- peer reviewed and published immediately upon acceptance

- cited in PubMed and archived on PubMed Central

- yours - you keep the copyright

Submit your manuscript here:

http://www.biomedcentral.com/info/publishing_adv.asp
BioMedcentral 